\begin{tabular}{|llll|l|}
\hline NOV & 0 & 5 & 1999 \\
STK & 8 & 5 & ENGINEERING DATA TRANSMITTAL & Pago 1 of 1 \\
\hline
\end{tabular}

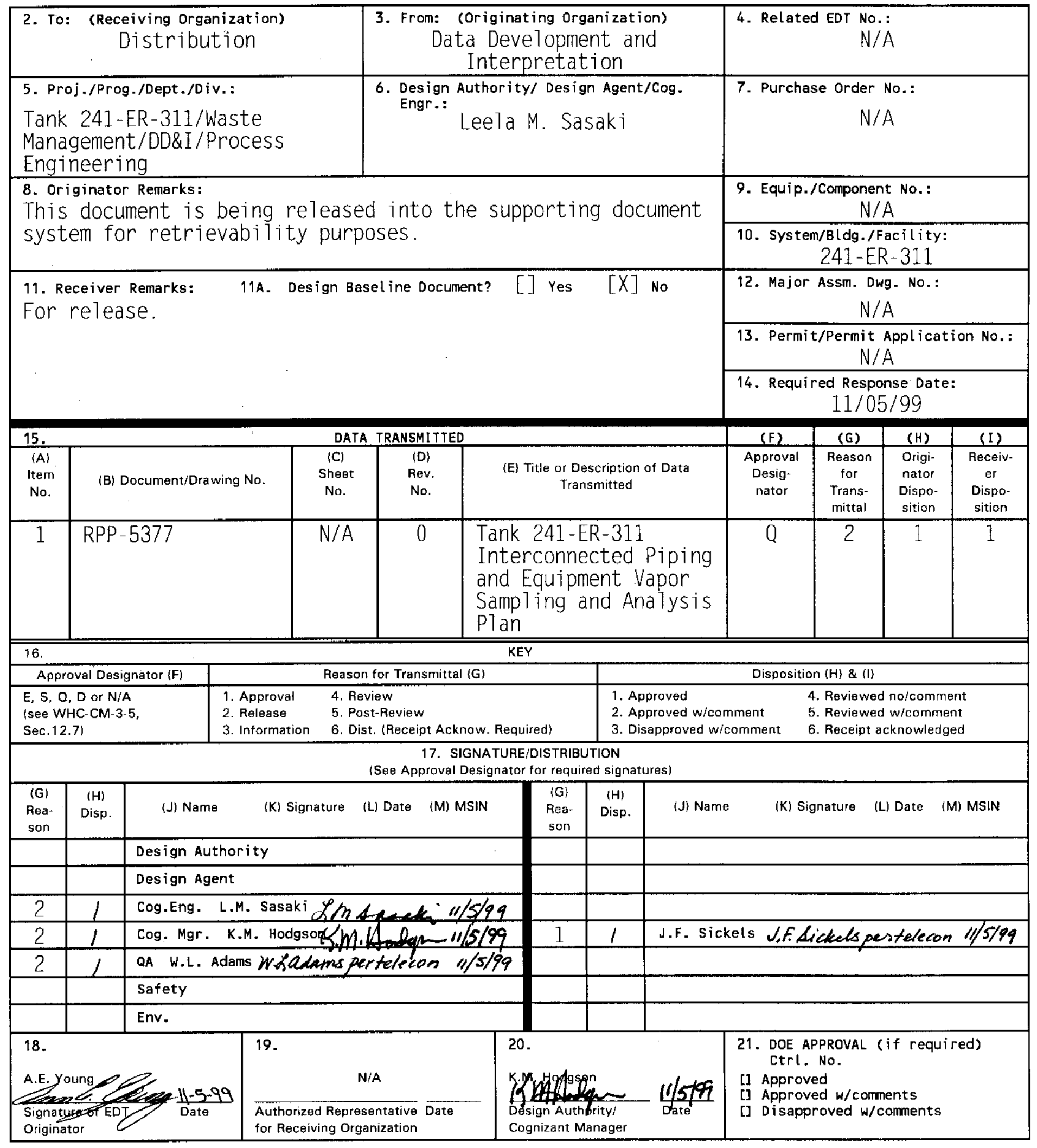

BD-7400-172-2(05/96) GEF097 


\section{Tank 241-ER-311 Interconnected Piping and Equipment Vapor Sampling and Analysis Plan}

Leela M. Sasaki

Lockheed Mart in Hanford, Corp., Richland. WA 99352

U.S. Department of Energy Contract DE-AC06-96RL13200

$\begin{array}{lll}\text { EDT/ECN: } & \text { EDT-627252 } & \text { UC: } 2070 \\ \text { Org Code: } & 74 B 40 & \text { CACN/COA: 102306/ES13 } \\ \text { B\&R Code: } & \text { EW } 3120074 & \text { Tota7 Pages: } 12\end{array}$

Key Words: Tank 241-ER-311, 241-ER-311, ER-311, Interconnected Piping. Piping, Equipment, Vapor, Sampling, Analysis, Plan

Abstract: N/A

TRADEMARK DISCLAIMER. Reference herein to any specific commercial product, process, or service by trade name, trademark, manufacturer, or otherwise, does not necessarily constitute or imply its endorsement, recommendation, or favoring by the United States Government or any agency thereof or its contractors or subcontractors.

Printed in the United States of America. To obtain copies of this document, contact: Document Control Services, P.0. Box 950, Mailstop H6-08, Richland WA 99352, Phone (509) 372-2420; Fax (509) 376-4989.
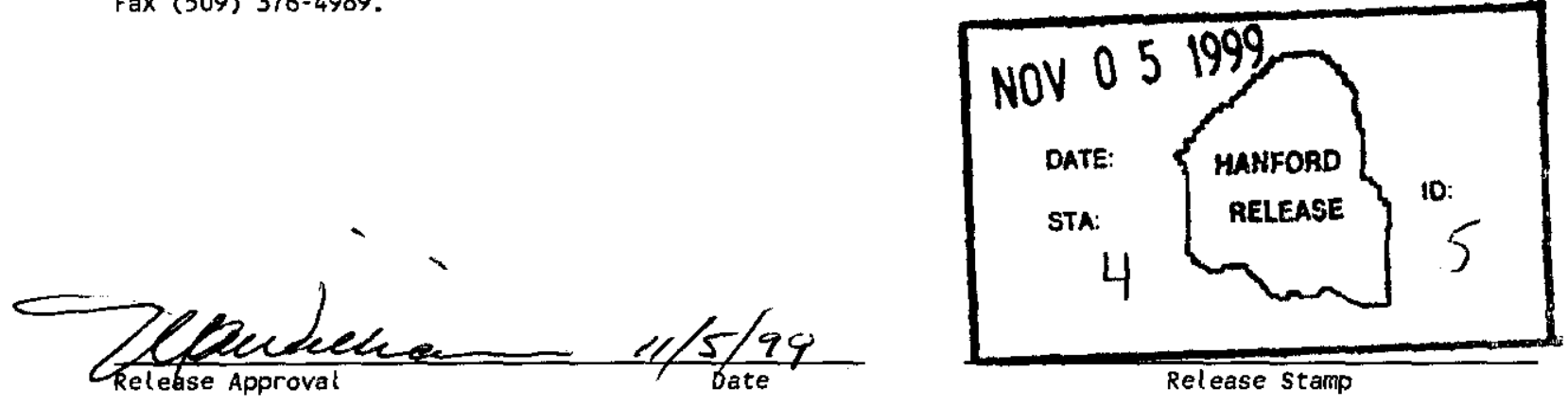

Release Stamp

\section{Approved for Public Release}




\section{Tank 241-ER-311 Interconnected Piping and Equipment Vapor Sampling and Analysis Plan}

L. M. Sasaki

Lockheed Martin Hanford Corporation

Prepared for the U.S. Department of Energy

Office of River Protection 


\subsection{SAMPLING AND ANALYSIS OBJECTIVES}

This sampling and analysis plan (SAP) identifies characterization objectives pertaining to sample collection, laboratory analytical evaluation, and reporting requirements for vapor samples obtained from piping, equipment, or facilities connected to tank 241-ER-311. The purpose of this sampling event is to obtain information about the effects of the argon purge gas added to tank 241-ER-311.

Vapor samples will be taken in the encasement of transfer lines, at the ER-151 diversion box, and, as necessary, any other locations connected to tank 241-ER-311. Combustible gas, ammonia, and organic vapor levels will be field-measured using hand-held instruments. Vapor samples will be taken and shipped to the Pacific Northwest National Laboratory (PNNL) for analysis.

This test plan identifies the sample collection, laboratory analysis, quality assurance, and reporting objectives for this data collection effort. The plan also provides the requirements for vapor measurements performed in the field. 


\subsection{SAMPLING EVENT REQUIREMENTS}

Field vapor measurements and vapor samples will be taken (1) in the encasement of transfer lines; (2) at the ER-151 diversion box; and, (3) as necessary, any other piping, equipment, or facilities connected to tank 241-ER-311. Table 2-1 lists locations to be sampled. Sample locations are listed in order of priority. Other locations may be sampled and analyzed in accordance with this sampling and analysis plan.

Table 2-1. Vapor Sampling Locations

\begin{tabular}{|l|l|l|}
\hline Facility or Transfer Line & Location & Alternative Location \\
\hline 241-ER-151 diversion box & $\begin{array}{l}\text { Electrical conduit into } \\
\text { diversion box }\end{array}$ & none \\
\hline $\begin{array}{l}\text { Cross-site transfer line } \\
\text { encasement }\end{array}$ & Test riser TR-1-EW & Test riser TR-2-EW \\
\hline $\begin{array}{l}\text { 241-ER-152 diversion box } \\
\text { drain line encasement }\end{array}$ & Test riser DRN-TR-2 & Test riser DRN-TR-1 \\
\hline $\begin{array}{l}\text { 244-BX transfer line } \\
\text { encasement }\end{array}$ & Test riser TR-2-G & Test riser TR-1-G \\
\hline $\begin{array}{l}\text { 244-AR vault transfer line } \\
\text { encasement }\end{array}$ & Test Riser TR-1-CF & Test Riser TR-2-CF \\
\hline
\end{tabular}

Gas levels will be measured in the field using portable or hand-held gas meters. The required field measurements are listed in Table 2-2. Vapor samples will be obtained using $60 \mathrm{~mL}$ Hoke samplers. Samples shall be shipped by Characterization Project Operations (CPO) to the 325 Building of PNNL for analysis. Prior to taking the measurements and obtaining vapor samples, the sampling system will be purged to assure that the sample system tubing is filled only with gas from the sample location.

Table 2-2. Field Measurements

\begin{tabular}{|c|c|}
\hline $\begin{array}{c}\text { Measurement } \\
\begin{array}{c}\text { Combustible gas level and } \\
\text { oxygen }\end{array}\end{array}$ & Measurement Methods \\
\hline Ammonia & Calorimetric (Draeger) Tubes \\
\hline Organic vapor & Organic Vapor Monitor (OVM) \\
\hline
\end{tabular}

Sampling Requirements for Electrical Conduit into 241-ER-151 Diversion Box

1. Record field measurements at conduit opening. If the CGM reading is above $25 \%$ of the lower flammability limit (LFL), obtain one $60 \mathrm{~mL}$ vapor sample at that location.

2. Record field measurements inside the diversion box.

3. Obtain one $60 \mathrm{~mL}$ vapor sample from inside the diversion box.

4. If tubing cannot be inserted through the conduit to the diversion box, it may be necessary to make measurements and collect the samples by purging the conduit. 
Sampling Requirements for Test Riser TR-1-EW

1. Record field measurements at top of open riser. If the CGM reading is above $25 \%$ of the lower flammability limit (LFL), obtain one $60 \mathrm{~mL}$ vapor sample at that location.

2. Record field measurements at approximately the midpoint between the top and bottom of the riser and record the sample depth. If the CGM reading is above $25 \%$ of the lower flammability limit (LFL), obtain one $60 \mathrm{~mL}$ vapor sample at that location.

3. Record field measurements inside the transfer line encasement (below the bottom of the riser) and record the sample depth.

4. Obtain one $60 \mathrm{~mL}$ vapor sample from inside the transfer line encasement.

Sampling Requirements for Test Riser DRN-TR-2

1. Record field measurements at top of open riser. If the CGM reading is above $25 \%$ of the lower flammability limit (LFL), obtain one $60 \mathrm{~mL}$ vapor sample at that location.

2. Record field measurements at approximately the midpoint between the top and bottom of the riser and record the sample depth. If the CGM reading is above $25 \%$ of the lower flammability limit (LFL), obtain one $60 \mathrm{~mL}$ vapor sample at that location.

3. Record field measurements inside the diversion box drain line encasement (below the bottom of the riser) and record the sample depth.

4. Obtain one $60 \mathrm{~mL}$ vapor sample from inside the diversion box drain line encasement.

Sampling Requirements for Test Riser TR-2-G

1. Record field measurements at top of open riser. If the CGM reading is above $25 \%$ of the lower flammability limit (LFL), obtain one $60 \mathrm{~mL}$ vapor sample at that location.

2. Record field measurements at approximately the midpoint between the top and bottom of the riser and record the sample depth. If the CGM reading is above $25 \%$ of the lower flammability limit (LFL), obtain one $60 \mathrm{~mL}$ vapor sample at that location.

3. Record field measurements inside the transfer line encasement (below the bottom of the riser) and record the sample depth.

4. Obtain one $60 \mathrm{~mL}$ vapor sample from inside the transfer line encasement.

Sampling Requirements for Test Riser TR-1-CF

1. Record field measurements at top of open riser. If the CGM reading is above $25 \%$ of the lower flammability limit (LFL), obtain one $60 \mathrm{~mL}$ vapor sample at that location.

2. Record field measurements at approximately the midpoint between the top and bottom of the riser and record the sample depth. If the CGM reading is above $25 \%$ of the lower flammability limit (LFL), obtain one $60 \mathrm{~mL}$ vapor sample at that location.

3. Record field measurements inside the transfer line encasement (below the bottom of the riser) and record the sample depth.

4. Obtain one $60 \mathrm{~mL}$ vapor sample from inside the transfer line encasement.

All vapor samples collected shall be identified by a unique sample number. Sample numbers assigned by Industrial Hygiene for vapor samples consist of the date, a sequential sample number, and technician's initials. Information recorded for each sample or set of field measurements shall include the facility or transfer line where the sample was taken, test riser number (or electrical conduit), depth of sample, and time and date of sampling.

Any decisions, observations, or deviations affecting this sampling and analysis plan shall be documented in controlled notebooks/or work package and justified in the deliverable report. 
RPP-5377, Rev. 0

\subsection{LABORATORY ANALYSIS REQUIREMENTS}

Vapor samples shall be analyzed by PNNL by analytical procedure PNNL-98523-284, Rev. 0 in accordance with the Gas Analysis Task (WBS 1.8) under the Flammable Gas Program. Analyses to be performed are listed in Table 3-1.

Table 3-1. Analytical Requirements for Vapor Samples

\begin{tabular}{|l|}
\hline \multicolumn{1}{|c|}{ Analytes } \\
\hline Argon \\
\hline Carbon dioxide \\
\hline Carbon monoxide \\
\hline Helium \\
\hline Hydrogen \\
\hline Methane \\
\hline Nitrogen \\
\hline Oxygen \\
\hline Nitrous oxide \\
\hline Other nitrogen oxides \\
\hline Other hydrocarbons \\
\hline Ammonia (estimated) \\
\hline
\end{tabular}


RPP-5377, Rev. 0

\subsection{QUALITY ASSURANCE AND QUALITY CONTROL}

\subsection{LABORATORY OPERATIONS}

The laboratory performing analyses in support of this sampling and analysis plan shall have an approved and implemented Quality Assurance (QA) Plan. This QA plan shall meet the Hanford Analytical Services Quality Assurance Requirements Document (DOE-RL 1998) minimum requirements as the baseline for laboratory quality systems. The PNNL QA Program for Conducting Analytical Work in Support of Regulatory Programs (PNNL1999) specifies the requirements for assuring the quality of sample analysis conducted at PNNL in support of this sampling and analysis plan.

Analytical quality control (QC) requirements shall be consistent with PNNL 1999. The laboratory shall also use calibration and calibration check standards appropriate for the analytical instrumentation being used (see DOE-RL [1998] for definitions of QC samples and standards). The criteria presented are goals for demonstrating reliable method performance. It is understood that the laboratory will follow its internal QC system for required actions whenever QC failures occur. If sample QC failures occur, or if all analyses cannot be performed (e.g., insufficient sample), analysts shall consult with supervisors/customers to determine the proper action. The laboratory should provide a suggested course of action at that time. All sample QC failures and limitations on the associated data shall be discussed in the narrative of the data report. Proper notification of all data not meeting QC requirements shall be included with the data.

\subsection{SAMPLE COLLECTION}

Samples are to be taken and shipped to the performing laboratory by CPO in accordance with the respective work packages. Chain-of custody will be carefully maintained to assure sample control at all times. The chain-of-custody forms for these work packages shall identify samples by a unique number. Sample numbers assigned by Industrial Hygiene for vapor samples consist of the date, a sequential sample number, and technician's initials. Pertinent sampling information (e.g., sample location, and unusual observations) should be noted on the chain-ofcustody form.

Characterization Project Operations should transport each sample collected to the performing laboratory as soon as possible after sampling.

Nonconforming sampling processes shall be identified, controlled, reported, and the disposition taken as required by the Nonconformance Item Reporting and Control (LMHC 1999). 


\subsection{EXCEPTIONS, CLARIFICATIONS, AND ASSUMPTIONS}

A combustible gas meter will be used to measure the flammable gas level in the headspace of a catch tank. The CGM will be calibrated using pentane gas. Actual CGM readings will be adjusted to percent LFL of hydrogen using a pentane-to-hydrogen conversion value recommended by the manufacturer. The assumption in the conversion is that the combustibility of the headspace vapor is due only to hydrogen. However, the presence of other combustible gases and vapors such as ammonia and organics could affect the results. Testing has shown that the CGM readings are conservative for gas mixtures (i.e., the instrument reports a higher percent LFL than that actually present for the gas mixtures tested) (Wilkins and Bauer 1996). Even so, it is desirable to determine whether or not the reported gas levels are due mainly to hydrogen or some other gases. Thus, ammonia and organic vapor concentrations will also be measured. 
RPP-5377, Rev. 0

\subsection{ORGANIZATION}

The organization and responsibility of key personnel involved with this characterization project are listed in Table 6-1.

Table 6-1. Project Key Personnel List

\begin{tabular}{|c|c|c|}
\hline Responsibility & Organization & Individual \\
\hline RPP Tank Coordinator & $\begin{array}{l}\text { RPP Process Engineering } \\
\text { (LMHC) }\end{array}$ & L. M. Sasaki, 373-1027 \\
\hline $\begin{array}{l}325 \text { Laboratory Point of } \\
\text { Contact }\end{array}$ & $\begin{array}{l}\text { Advanced Inorganic Analysis } \\
\text { (PNNL) }\end{array}$ & S.J. Bos, $376-5384$ \\
\hline $\begin{array}{l}200 \text { East Tank Farm Point of } \\
\text { Contact }\end{array}$ & $\begin{array}{l}\text { Tank Farm Operations } \\
\text { (LMHC) }\end{array}$ & D. G. Baide, 376-3274 \\
\hline $\begin{array}{l}\text { Process Engineering Point of } \\
\text { Contact }\end{array}$ & $\begin{array}{l}\text { Manager, Inventory Control } \\
\text { and Modeling (LMHC) }\end{array}$ & K. M. Hodgson, $373-3513$ \\
\hline $\begin{array}{l}\text { Flammable Gas Program Point } \\
\text { of Contact }\end{array}$ & $(\mathrm{LMHC})$ & G. D. Johnson, 373-1324 \\
\hline
\end{tabular}


RPP-5377, Rev. 0

\subsection{DELIVERABLES}

Preliminary analytical results shall be reported as soon as possible. Preliminary results are requested within one working day of the receipt of the samples. The results of the analyses are to be reported to the individuals listed in Table 6-1 via electronic mail. Final results shall be documented in a letter distributed to the individuals listed in Table 6-1. At a minimum, the letter shall contain sample identification, all analytical results, estimate of analytical precision, and analytical procedures used. The letter report shall be issued within two working days of the receipt of the samples. 


\subsection{CHANGE CONTROL}

Under certain circumstances, it may become necessary for the performing laboratory to make decisions concerning a sample without review of the data by the customer or the Characterization Project. All significant changes (such as analyte additions or analysis of new, additional samples) shall be documented by RPP Process Engineering via an Engineering Change Notice to this sampling and analysis plan. All changes shall also be clearly documented in the final data report. 
RPP-5377, Rev. 0

\subsection{REFERENCES}

DOE-RL, 1998, "Hanford Analytical Services Quality Assurance Requirements Document, "DOE/RL-96-68, Rev. 2, U.S. Department of Energy, Richland Operations Office, Richland, Washington.

LMHC, 1999, "Nonconformance Item Reporting and Control," LMH-PRO-298, Rev. 0, Lockheed Martin Hanford Corporation, Richland, Washington.

PNNL, 1999, "PNNL QA Program for Conducting Analytical Work in Support of Regulatory Programs," http:/quality.pnl.gov/Guidance/QualityAssurancePlanning/index.htm, Pacific Northwest National Laboratory, Richland, Washington.

Wilkins, N. E., and Bauer, R. E., 1996, "Test Evaluation of Industrial Hygiene Hand Held Combustible Gas Monitor," WHC-SD-WM-TRP-256, Rev. 0, Westinghouse Hanford Company, Richland, Washington. 


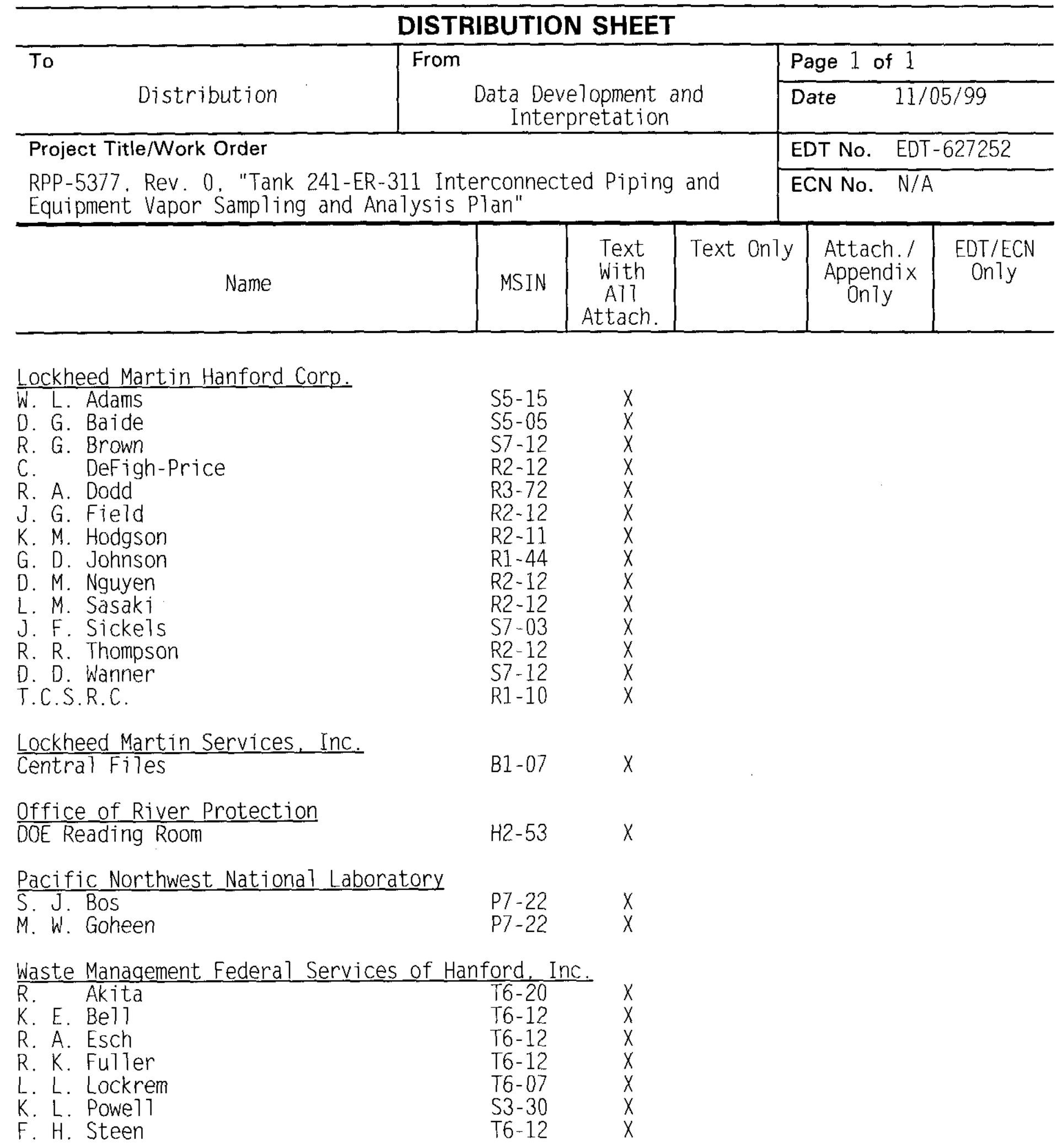

